\title{
Pesquisa das deleções $-\alpha 3.7$ e $-\alpha 4.2$ no agrupamento de genes da alfa globina humana e avaliação do perfil clínico-laboratorial em indivíduos com fenótipo de hemoglobina AS Study of the - $\alpha 3.7$ and - $\alpha 4.2$ deletions in the group of genes of human alpha globin and evaluation of the clinical-laboratory profile in individuals with the hemoglobin $A S$ phenotype
}

Tatiana L. S. Nogueira

Orientadora: Georgina S. Ribeiro

\section{Resumo}

No Brasil, estudos têm revelado uma maior frequência da deleção $-\alpha 3.7$ e raros relatos da deleção - $\alpha 4$.2. O presente estudo teve como objetivo avaliar os indivíduos com fenótipo de hemoglobina AS e pesquisar a presença da alfa talassemia nessa população. Foram selecionados 61 indivíduos de acordo com o fenótipo de hemoglobina AA e AS. Todos foram submetidos à análise molecular das deleções $-\alpha 3.7$ e $-\alpha 4.2$ e avaliação dos perfis hematológico, bioquímico e urinário. O VCM médio $(79,85 \mathrm{fL} \pm 3,2)$ foi significativamente menor $(\mathrm{p}<0,0001)$ nos indivíduos AS com alfa talassemia. Nos parâmetros bioquímicos, a média do ferro sérico nos indivíduos com fenótipo $\mathrm{AA}(77 \mathrm{mcg} / \mathrm{dL} \pm 30)$ foi significativamente menor $(\mathrm{p}=0,013)$ que nos indivíduos $\mathrm{AS}(98 \mathrm{mcg} / \mathrm{dL} \pm 34)$, porém, ambos dentro dos limites normais. Os demais parâmetros, ferritina, transferrina, capacidade de fixação do ferro, bilirrubinas totais e frações e lactato desidrogenase não evidenciaram diferenças relevantes. Não foi observada diferença estatística $(p=1,000)$ entre os grupos quanto à presença de hemoglobinúria e hematúria. A frequência de alfa talassemia na população estudada foi de $25,0 \%$. Nos indivíduos AS, $13,3 \%$ apresentaram interação com a talassemia- $\alpha+(-\alpha 3.7 / \alpha \alpha)$. Entre os indivíduos com fenótipo de hemoglobina normal, cinco $(8,3 \%)$ eram heterozigotos para a deleção - $\alpha 3.7$ e um $(1,7 \%)$ foi heterozigoto para a deleção - $\alpha 4$.2. Foi detectado, ainda, um $(1,7 \%)$ indivíduo portador de hemoglobina variante de cadeia alfa não identificada em associação com a talassemia- $\alpha+(-\alpha 3.7 / \alpha \alpha)$. O diagnóstico molecular para a alfa talassemia (deleção de um gene) é de extrema importância, tanto para portadores de traço falciforme quanto para indivíduos com fenótipo AA, mesmo na ausência de parâmetros hematológicos alterados, ressaltando que a utilização de microcitose e hipocromia como critério diagnóstico para alfa talassemia pode subestimar as frequências desta alteração genética.

Palavras-chave: Traço falciforme; alfa talassemia; deleção $-\alpha 3.7$; deleção $-\alpha 4.2$

Dissertação para obtenção de título de Mestre, apresentada à Faculdade de Medicina da Universidade Federal Fluminense, Centro de Ciências Médicas - Programa de Pós-graduação em Patologia, Area de Concentração: Patologia Clínica e Análises Clínicas. UFF, Niterói-RJ.

Correspondência: Tatiana Lúcia Santos Nogueira

Rua Francisco Manoel, 102 - Benfica

20911-270 - Rio de Janeiro-RJ - Brasil

E-mail: tatianalsnogueira@hotmail.com

\begin{abstract}
In Brazil, studies have shown a high frequency of the $-\alpha 3.7$ deletion and rare reports of the $-\alpha 4.2$ deletion. This study aimed at evaluating individuals with the hemoglobin AS phenotype and investigating the presence of alpha thalassemia in this population. Sixty-one individuals with hemoglobin AS and AA phenotypes were selected. All were submitted to molecular analysis of the $\alpha 3.7$ and $-\alpha 4.2$ deletions and evaluation of hematologic, biochemical and urinary profiles. The mean VCM (79.85 fL \pm 3.2$)$ was significantly lower $(\mathrm{p}<0.0001)$ in individuals with alpha thalassemia. The mean serum iron concentration was significantly lower in individuals with the AA phenotype $(77 \mathrm{mcg} / \mathrm{dL} \pm 30-\mathrm{p}=$ 0.013 ) compared to AS individuals $(98 \mathrm{mcg} / \mathrm{dL} \pm 34$ ) however, both levels were within the normal range. The other parameters, including ferritin, transferrin, total iron binding capacity, total bilirubin, bilirubin fractions and lactate dehydrogenase showed no significant differences. Statistically significant differences were not observed between the groups in respect to hemoglobinuria and hematuria. The frequency of alpha thalassemia in the studied population was $25.0 \%$. Of the AS individuals, $13.3 \%$ presented interactions with $-\alpha+$ thalassemia $(-\alpha 3.7 / \alpha \alpha)$. Among individuals with normal hemoglobin phenotypes, five $(8.3 \%)$ were heterozygous for the $-\alpha 3.7$ deletion and one individual (1.7\%) was heterozygous for the $-\alpha 4.2$ deletion. One individual (1.7\%) was identified with a non-identified alpha chain variant in association with $-\alpha+$ thalassemia $(-\alpha 3.7 / \alpha \alpha)$. The molecular diagnosis of alpha thalassemia (deletion of one gene) is of extreme importance, both for patients with sickle cell trait and for individuals with the AA phenotype, even in the absence of altered hematological parameters. It is important to remember that the use of microcytosis and hypochromia as diagnostic criteria for alpha thalassemia may underestimate the frequencies of this genetic alteration.
\end{abstract}

Key words: Sickle cell trait; alpha thalassemia; - $\alpha 3.7$ deletion; $-\alpha 4.2$ deletion.

\begin{abstract}
Avaliação: A RBHH publica os resumos e abstracts de teses da área apresentados em entidades que tenham programas de pós-graduação reconhecidos pelo MEC/Capes e considera a obtenção do título suficiente para sua publicação na forma como se propõe a seção.
\end{abstract}

Recebido: 04/02/2009

Aceito: 04/02/2009 